\title{
PARENTS IN SPORT. PARENT-INITIATED MOTIVATIONAL CLIMATE AND GOAL ORIENTATION IN SPORT
}

\author{
Tatiana Iancheva \\ National Sports Academy "Vassil Levski", Sofia, Bulgaria
}

\begin{abstract}
Introduction: The role of parents in contemporary sport is much more frequently researched nowadays. In the recent years the balance in the triangle "coach-athlete-parent" has often been disrupted. On the one hand, the positive role of parents has been emphasized. On the other hand, the high expectations and pressure on behalf of parents may turn into a serious negative factor. This manuscript presents the results from a survey of Parent-initiated motivational climate and its relation to Perceived Motivational Climate and Goal orientation in sport.

The aim of present study is to research Parent-Initiated Motivational Climate among athletes practicing different kinds of sport and to seek its relations with Perceived Motivational Climate in Sport Questionnaire and Goal orientation in Sport.

Methodology: The research was done among 114 competitors practicing 5 kinds of sport (volleyball, fencing, rhythmic gymnastics, football, and tennis) aged between 11 and 17 years, divided into groups according to their sport, gender and qualification.

We used: 1) Parent-Initiated Motivational Climate Questionaire-2 (PIMCQ-2), White and Duda, 1993. 2) Task and Ego orientation in Sport Questionnaire (Duda \& Nicholls, 1992), adapted for Bulgarian conditions (DomuschievaRogleva, 2003); 3) Perceived Motivational Climate in Sport Questionnaire (PMCSQ-2) (Newton, Duda, \& Yin, 2000), adapted for Bulgarian conditions (Domuschieva-Rogleva, 2003).

Results: The subscales Learning and enjoyment climate and Mother and Father had the highest values. Task orientation and Perceived task-involving climate are domineering in the researched sample. There were significant correlation dependences between the researched parameters. There were significant differences as regards the factors sport and gender. The results from the regression analysis showed that Parent-Initiated Motivational Climate influenced Perceived Motivational Climate and Goal orientation.

Discussion: The obtained results from the research, as a whole, confirm the data found in literature, but reveal certain specificity in the Bulgarian conditions. The relation between Parent-Initiated Motivational Climate, Perceived Motivational Climate and Goal orientation is confirmed. A significant for practice is the established fact that parents' stimulated Worry-conductive Climate and Success without effort climate enhance Ego Orientation, associated with neutral or less optimal outcomes particularly when perceptions of competence are low or not accompanied by taskbased goals.
\end{abstract}

Key words: Parent-Initiated Motivational Climate, Task orientation, Ego orientation, Coping strategies, Perceived Motivational Climate.

\section{INTRODUCTION}

The interest towards the role and influence of parents on young athletes' development and their sports career has been increased in sports-psychological literature in recent years. Parents' behavior has been viewed as one of the major situational and contextual factors. Part of the surveys have been aimed at the way parents interact with their children before, during, and after competition (Holt et al., 2008; Dorsch et al., 2015; Tamminen et al., 2017). Others have emphasized on parents' influence on young athletes' perceptions, their own abilities and motivation (Dweck, 1986; Nicholls, 1989; Ames, 1992), on their education and socialization, personal and social development (Knight, Dorsch, Osai, Haderlie, \& Sellars, 2016, Pomerantz \& Thompson, 2008), on the impact of the relationships between parents and their children and its importance for the sports result (O'Rourke, Smith, Smoll, \& Cumming, 2013). Some authors point out that the influence can be both positive - through an encouraging and supportive behavior, and negative - perceived as inadequately demanding, pressing in competition, critical to sports failures 
(Knight, Bodem, \& Holt, 2010, Knight, Neely, \& Holt, 2011). Gomes et al. (2010) connect parents' behavior with cognitive assessment and motivation (Gomes, Goncalves, Dias, \& Morais, 2010). Parents influence significantly young athletes' perceptions about their abilities and motivation.

Some authors emphasize on the change in the specific role of the participants in the triangle "coach-athlete-parent" in the preparation and development of talent (Iancheva, 2019).

The role of parents in contemporary sport is undisputable. But in recent years the balance in the triangle "coach-athlete-parent" has often been disrupted. On the one hand, the positive role of parents and the need of maintaining good interaction are emphasized. On the other hand, the high expectations and pressure on behalf of parents and even interference in coaches' work and sports-technical management have been reported to become a serious negative factor (Wolfenden \& Holt, 2005, Iancheva, 2019) which may provoke a significant tension in athletes' preparation and realization.

Nicholl's achievement goal theory is one of the most widely used theoretical frameworks within the sport psychology literature and addresses the intrapersonal and situational factors which influence individuals' cognitive perceptions of success and failure, their attributions, affective responses, and subsequent behaviors (Roberts, 2001; Smith et al., 2008). Individuals' achievement goals within specific situations are determined by an interaction between their goal orientations and the motivational climate created by key social agents (e. g. parents, coaches, peers) (Dweck and Leggett, 1988; Harwood et al., 2008; Harwood et al., 2019).

Achievement Goal Theory suggests that individuals have two kinds of dominant individualistic goal orientations. First of them, task orientation, focuses on individualistic achievement and progress due to effort, while ego orientation, which is the second goal orientation, means having a better performance and obtaining better results. Athletes, who simultaneously have higher task and ego tendency, or athletes with high task tendency and low level of ego tendency, show more adaptive motivational patterns than those with a low task orientation (Moreno, Cervello, \& Cutre, 2010). High levels of task-orientation are associated with positive cognitive, affective, and behavioral outcomes, while high levels of ego-orientation are associated with neutral or less optimal outcomes particularly when perceptions of competence are low or not accompanied by task-based goals (Biddle et al., 2003; Harwood et al., 2008; Harwood et al., 2019).

According to Achievement Goal Theory, a situational level, there are two types of motivational climate (Ames, 1992) that influence an individual's achievement goal state in an achievement context such as youth sport competition. A mastery/ task-involving climate is created when social agents are perceived to place emphasis on self-referenced improvement, effort, and cooperative learning. Performance/ego involving climate is created when there is a perceived focus on outcomes, the emphasis is placed on outperforming others.

In this context, the aim of present study is to research Parent-Initiated Motivational Climate among players from different kinds of sport and to seek its relations with Perceived Motivational Climate in Sport Questionnaire and Goal orientation in Sport.

\section{METHODOLOGY}

\section{Participants}

The research was done among 114 athletes practicing five kinds of sport (volleyball, fencing, rhythmic gymnastics, football, and tennis) aged between 11 and 17 years, with sports experience $\mathrm{M}=7,07$ years $(\mathrm{SD}=2,50)$. The mean age of the subjects is $13,83(\mathrm{SD}=1,88)-53$ boys $(\mathrm{M}=14,00$; $\mathrm{SD}=1,57)$ and 61 girls $(\mathrm{M}=13,69 ; \mathrm{SD}=2,11)$.

At the beginning of the research all participants were informed about the aim of the research and granted their agreement to participate.

\section{Measures}

In order to fulfill the aim of the research we used:

1. Parent-Initiated Motivational Climate Questionaire-2 (PIMCQ-2), White and Duda, 1993. The questionnaire includes three subscales for mothers and three subscales for fathers referring to the task involving climate (Learning/Enjoyment Climate) and ego involving climate (Worry-Conductive Climate and Success Without Effort). The questionnaire has very goof psycho-metric characteristics in Bulgarian conditions (LCM $\alpha=.763$; WCCM $\alpha=$ .774; SWEM $\alpha=.817$; LCF $\alpha=.733$; WCCF $\alpha=$ .737; SWEF $\alpha=.836$ ). 
2. Taskand Ego Orientation in SportQuestionnaire - TEOSQ (Duda \& Nicholls, 1992) was adapted for Bulgarian conditions by DomuschievaRogleva, 2003. The questionnaire contains two subscales: task orientation and ego orientation.

3. Perceived Motivational Climate in Sport Questionnaire (PMCSQ-2) (Newton, Duda, \& Yin, 2000) was adapted for Bulgarian conditions by Domuschieva-Rogleva, 2003. The PMCSQ-2 includes two higher order dimensions: the perceived task-involving climate and the perceived ego-involving climate. Each contains three first-order subdimensions. The perceived task-involving climate: cooperative learning, effort and improvement and important role, the perceived ego-involving climate: in-team member rivalry, unequal recognition and punishment for mistakes.

Statistical Analysis

The assessment of the initial data from the research was made with the statistical packet SPSS 21 . We made Reliability analysis, Correlation, Regression, and Comparative analysis (U-criterium of Mann Whitney and criterium of Kruskal Wallis).

\section{RESULTS AND DISCUSSION}

Table 1 presents the results from the descriptive statistics.

The analysis of the results from our research of Parent-Initiated Motivational Climate revealed that the subscales Learning and enjoyment climate Mother and Father had the highest values $(\mathrm{Mm}=4.22$; $\mathrm{Mf}$ $=4.36$ ), i.e. parents' stimulation of a climate aimed at development and improvement of skills and perfection through investing the necessary efforts. The next subscales were Worry-conductive climate $(\mathrm{MM}=2.35 ; \mathrm{Mf}=2.24)$ and Success without effort climate $(\mathrm{Mm}=1.96 ; \mathrm{Mf}=1.99)$. Our results, as a whole, confirm the data in literature (Veskovic at al., 2013; Kolayis at al., 2017; Gomes at al., 2019).

Table 1. Descriptive statistics of study variables

\begin{tabular}{|c|c|c|c|c|c|c|}
\hline & & $\mathbf{N}$ & Min & Max & $\mathbf{M}$ & SD \\
\hline \multirow{3}{*}{ Mother } & Learning and enjoyment climate & 114 & 1.00 & 5.00 & 4.22 & .63 \\
\hline & Worry-conductive climate & 114 & 1.00 & 4.80 & 2.35 & .87 \\
\hline & Success without effort climate & 114 & 1.00 & 5.00 & 1.96 &, 84 \\
\hline \multirow{3}{*}{ Father } & Learning and enjoyment climate & 114 & 2.80 & 5.00 & 4.39 & .56 \\
\hline & Worry-conductive climate & 114 & 1.00 & 4.60 & 2.24 & .81 \\
\hline & Success without effort climate & 114 & 1.00 & 5.00 & 1.99 & .95 \\
\hline \multirow{6}{*}{$\begin{array}{l}\text { Perceived task-in- } \\
\text { volving climate }\end{array}$} & Task orientation & 114 & 3.14 & 5.00 & 4.39 & .48 \\
\hline & Ego orientation & 114 & 1.00 & 4.33 & 2.33 & .81 \\
\hline & Task-involving & 114 & 3.59 & 5.00 & 4.40 & .36 \\
\hline & Important role & 114 & 3.28 & 5.00 & 4.44 & .41 \\
\hline & Effort/improvement & 114 & 2.83 & 5.00 & 4.52 & .43 \\
\hline & Cooperative learning & 114 & 2.25 & 5.00 & 4.17 & .54 \\
\hline \multirow{4}{*}{$\begin{array}{l}\text { Perceived } \\
\text { ego-involving } \\
\text { climate }\end{array}$} & Ego-involving & 114 & 1.29 & 3.88 & 2.41 & .35 \\
\hline & Unequal recognition & 114 & 1.00 & 4.14 & 2.29 & .65 \\
\hline & Punishment & 114 & 1.00 & 3.75 & 2.32 & .72 \\
\hline & Intrateam member rivalry & 114 & 1.00 & 5.00 & 2.73 & .79 \\
\hline
\end{tabular}

Task orientation and Perceived task-involving cli- vealed significant differences as regards Perceived mate are domineering in the researched sample ego-involving climate, Effort, Punishment, Success (Table 1). without effort Mother, Learning F, Success without The comparative analysis along the factor sport re- effort Father (Table 2).

Table 2. Results from the comparative analysis along the factor sport

\begin{tabular}{|l|l|l|l|l|l|l|}
\hline & $\begin{array}{c}\text { Ego-involving } \\
\text { climate }\end{array}$ & Effort & Punishment & SuccessWEM & LearningF & SuccessWEF \\
\hline Chi-Square & 10,586 & 16,095 & 26,306 & 10,970 & 9,467 & 10,291 \\
\hline df & 3 & 3 & 3 & 3 & 3 & 3 \\
\hline Asymp. Sig. &, 014 &, 001 &, 000 &, 012 &, 024 &, 016 \\
\hline
\end{tabular}


The highest results as regards Ego-involving climate were established for the athletes practicing fencing, and the lowest - as regards the invested efforts and increase in skills of these competitors. The motivational climate related to more efforts and improvement of skills was domineering for the rhythmic gymnasts. They had the lowest values in Success without effort climate (Father).

The results from the comparison analysis along the factor gender are presented in Table 3.

Table 3. Results from the comparison analysis along the factor gender

\begin{tabular}{|l|l|l|l|l|}
\hline & \multicolumn{1}{|c|}{ Task-involving climate } & \multicolumn{1}{|c|}{ Effort } & \multicolumn{1}{|c|}{ Punishment } & \multicolumn{1}{c|}{ LearningF } \\
\hline Mann-Whitney U & 648,500 & 568,500 & 510,500 & 500,500 \\
\hline Wilcoxon W & 1428,500 & 1348,500 & 1290,500 & 1535,500 \\
\hline Z & $-2,058$ & $-2,807$ & $-3,311$ & $-3,415$ \\
\hline Asymp. Sig. (2-tailed) &, 040 &, 005 &, 001 &, 001 \\
\hline
\end{tabular}

Perceived task-involving climate was significantly The results from correlation analysis of the data remore strongly expressed among women. They are vealed significant relations between the subscales much more willing to invest efforts, to increase of Parent-Initiated Motivational Climate, Task and their skills. They suffer more strongly the punish- Ego orientation and Perceived Motivational Climents for mistakes made. They had lower values for mate (Figure 4).

Learning and enjoyment climate (Father).

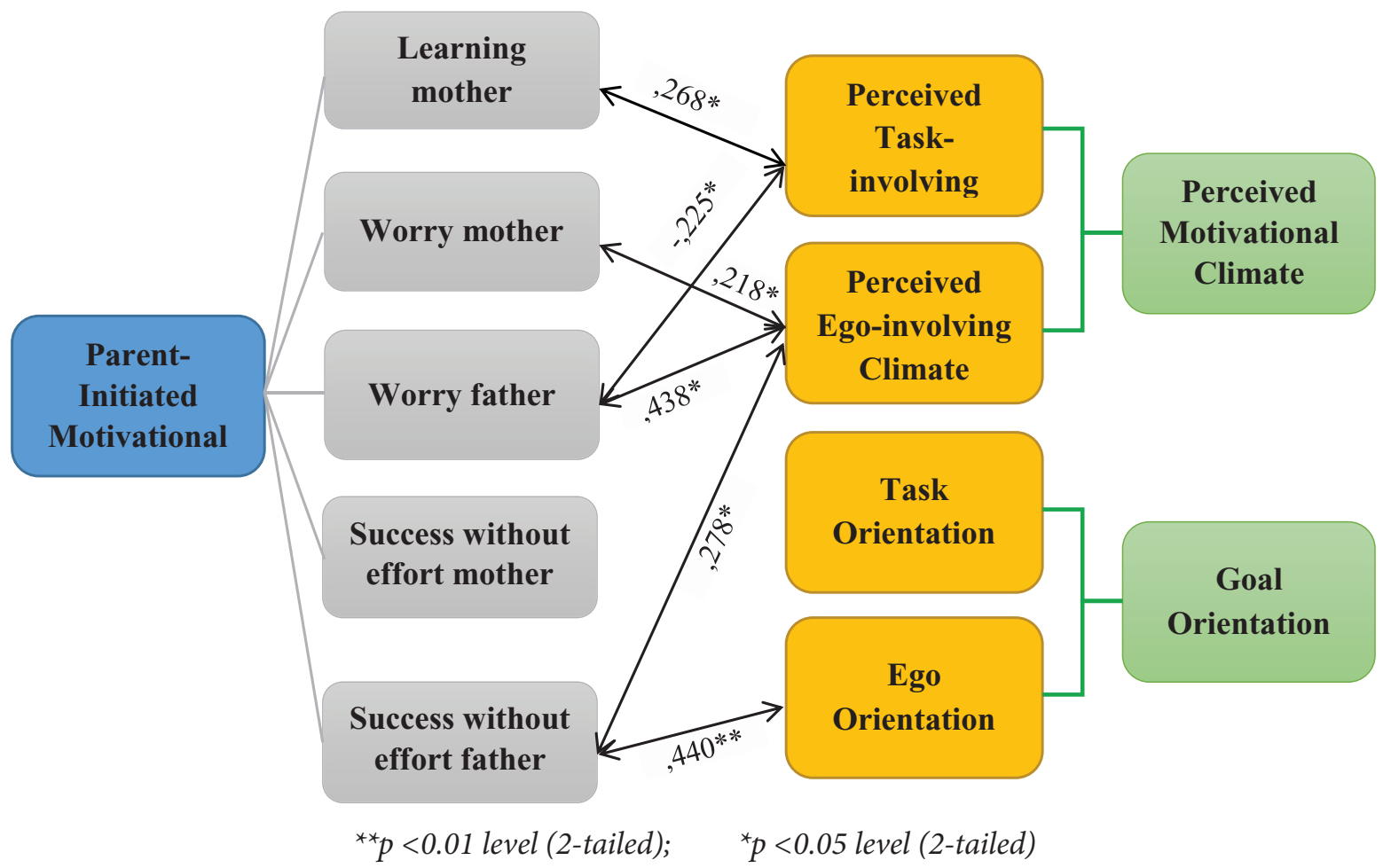

Figure 1. Results from correlation analysis

We established significant correlation dependencies between Perceived task-involving climate, Learning and enjoyment climate (Mother) $-\mathrm{r}=$ ,268*, and Worry-conductive climate (Father) $-r=$ ,$- 225^{\star}$, between Ego-involving climate, Worry-conductive climate (Father) $-\mathrm{r}=, 438^{* *}$, Worry-conductive climate (Mother) $-\mathrm{r}=, 218^{*}$, and Success without effort (Father) - ,278*, between Ego Orientation and Success without effort (Father) $-r=$
, $440^{\star *}$. The results make us believe that anxious behavior initiated by parents is related to goal orientation towards ego, towards motivational climate aimed at performance and seeking success without efforts.

The results from the regression analysis showed that Parent-Initiated Motivational Climate stimulate Perceived Motivational Climate (figure 1) and Goal orientation. Learning mother influences Per- 
ceived Task Motivational Climate $\left(\beta=.268^{\star}\right)$. Par- Climate. Success without effort climate (mother ents' initiated Worry-conductive Climate (mother and father) influences Ego orientation. and father) stimulates Perceived Ego Motivational

Table 4. Regression analysis

\begin{tabular}{|c|c|c|c|c|}
\hline & $\beta$ & $t$ & Sig. & $\Delta \mathrm{R}^{2}$ \\
\hline $\begin{array}{l}\text { Learning mother: } \\
\text { Perceived Task-involving Climate }\end{array}$ & .268 & 2.519 & .005 & .072 \\
\hline $\begin{array}{l}\text { Worry-conductive Climate mother: } \\
\text { Perceived Ego-involving Climate }\end{array}$ & .218 & 3.322 & .005 & .081 \\
\hline $\begin{array}{l}\text { Success without effort climate mother: } \\
\text { Ego Orientation }\end{array}$ & .286 & 2.704 & .005 & .071 \\
\hline $\begin{array}{l}\text { Worry-conductive Climate father: } \\
\text { Perceived Ego-involving Climate } \\
\text { Task Orientation }\end{array}$ & $\begin{array}{r}.445 \\
-.218\end{array}$ & $\begin{array}{c}4.583 \\
-2.250\end{array}$ & $\begin{array}{l}.000 \\
.001\end{array}$ & $\begin{array}{l}.182 \\
.221\end{array}$ \\
\hline $\begin{array}{l}\text { Success without effort climate father: } \\
\text { Ego Orientation }\end{array}$ & .524 & 4.431 & .000 & .183 \\
\hline
\end{tabular}

\section{DISCUSSION}

The obtained results from our research, as a whole, confirm the data in literature, but reveal a certain specificity in Bulgarian conditions. The relation between Parent-Initiated Motivational Climate, Perceived Motivational Climate and Goal orientation (Veskovic at al., 2013; Kolayis at al., 2017; Gomes at al., 2019, Atkins, et al., 2015; Davies, Babkes, Nichols, \& Coleman, 2016; O'Rourke, et al., 2013, 2014) is confirmed.

Learning and enjoyment climate Mother and Father are domineering in the researched sample, i.e. parents' stimulating a climate aimed at development and improvement of skills, perfection through investing the needed efforts, Task orientation, and Perceived task-involving climate. The established fact that parents' stimulated Worry-conductive Climate and Success without effort climate enhance Ego Orientation, associated with neutral or less optimal outcomes particularly when perceptions of competence are low or not accompanied by taskbased goals (Biddle et al., 2003; Harwood et al., 2008; Harwood et al., 2019) is important for practice. Parents' initiated anxious behavior is related to goal orientation towards ego, towards motivational climate aimed at performance and seeking success without efforts.

The obtained results from our research allow for discussing in more details and much more seriously the issue about parents' role in contemporary sport. The disrupted balance in the triangle "coach-athlete-parent" may lead to some negative effects and influence negatively athletes' competitive and worldly realization.

At the same time, we should point out the established specificity in the motivational climate in the researched sports. This sets the question about research on motivational climate in the context of the environment and its subjects: coaches, athletes, parents, management, as well as a consideration for the specifics of sports environment.

This study has some limitations related to the amount of the researched sample and the number of the included sports. Broadening the range of research would allow a more detailed analysis and interpretations.

\section{REFERENCES}

Ames, C. (1992). Achievement goals, motivational climate, and motivational processes, in Motivation in Sport and Exercize, ed. G. C. Roberts, Champaighn, 11, Human Kinetics, 161-176.

Atkins, M. R., Johnson, D. M., Force, E. C., \& Petrie, T. A. (2015). Peers, parents, and coaches, oh my! The relation of the motivational climate to boys 'intention to continue in sport. Psychology of Sport and Exercise, 16, 170-180.

Biddle, S. J. H., Wang, C. K., Kavussanu, M., and Spray, C. (2003). Correlates of achievement goal orientations in physical activity a systematic review of research. Eur. J. Sport Sci, 3, 1-20. Doi:10.1080/17461390300073504 
Davies, M. J., Babkes Stellino, M., Nichols, B. A., \& Coleman, L. M. (2016). Other-initiated motivational climate and youth hockey players'good and poor sport behaviors. Journal of Applied Sport Psychology, 28(1), 78-96.

Dorsch, T. E., Smith, A. L., Wilson, S. R., and McDonough, M. N. (2015). Parent goals and verbal sideline behavior in organized youth sport. Sport Exercise Performance Psychology, 4, 19-35, doi.... titive

Dweck, C. S. (1986). Motivational processes affecting learning, Am. Psychol., 41, 1040-1048, doi: 10.1037/0003066X.41.10.1040.

Dweck, C. S., and Leggett, E. L. (1988). A social-cognitive approach to motivation and personality, Psychological Revue. 95, 256-273. Doi: 10.1037/0033-295X.95.2.256 Gomes, A. R., Goncalves, A. M., Dias, O., Morais, C. (2019). Parental Behavior, Cognitive Appraisal, and Motivation in Young Athletes, Research Quarterly for Exercise and Sport, Vol. 90, NO. 1, 80-94.

Harwood, C. G., Calgar, E., Thrower, S., and Smith, (2019). Development and Validation of the Parent-Initiated Motivational Climate in Individual Sport Competition Questionnaire, Frontiers in Psychology, published: 05 February 2019, doi: 10.3389/fpsyg.2019.00128

Harwood, C. G., Spray, C. M., and Keegan, R. (2008). Achievement goal theories in sport, in Advances in Sport Psychology, ed. T. S. Horn (Champaign, IL: Human Kinetics), 157-185.

Holt, N. L., Tamminen, K. A., Biack, D. E., Sehn, Z. I., and Wall, M. P. (2008). Parental involvementin competitive youth sport settings. Sport Exercise Performance Psychology, 9, 663-685

Iancheva, T. (2017). Dvoinata kariera v sporta. Lichnost, Motivacia, Sport, T.21, Sofia, NSA Press, pp. 6-14 // Янчева, Т. (2017). Двойната кариера в спорта, Личност. Мотивация. Спорт., Т. 21, С., НСА ПРЕС, C. 6-14.

Iancheva, T. (2019). Psihologicheski problem I predizvikatelstva pred suvremennia eliten sport. Lichnost, Motivacia, Sport, T.23, Sofia, NSA PRESS, pp.5-14 // Янчева, Т. (2019). Психологически проблеми и предизвикателства пред съвременния елитен спорт, Личност. Мотивация. Спорт., Т. 23, С., НСА ПРЕС, C. 5-14.

Knight, C. J., Dorsch, T. E., Osai, K. V., Haderlie, K. L., \& Sellars, P. A. (2016). Influences on parental involvement in youth sport, Sport, Exercise, and Performance Psychol- ogy, 5 (2), 161-178, doi: 10.1037/spy/0000053.

Nicholls, G. (1989). The Competitive E.... and Democratic Education, Cambridge, MA, Harvard University Press. O’Rourke, D. J., Smith, R. E., Smoll, F. L., \& Cumming, S. P. (2013). Parent-initiated motivational climate and young athlets' intrinsic-extrinsic motivation: Cross-sectional and longitudinal relation. Journal of Child and Adolescent Behavior, 1(2), 109. Doi: 10.4172/jcalb.1000109 Pomerantz, E. M., \& Thompson, R. A., (2008). Parents' role in children's personality development: The psychological resource principle. In O. P. John, R. W. Robins, \& L. A. Pervin (Eds), Handbook of personality: Theory and research (Vol. 3, pp.353-374). New York, NY: Guilford Press.

Roberts, G. C. (2001). Understanding the dynamics of motivation in physical activity: the influence of achievement goals on motivational processes, In Advances in Motivation in Sport and Exercise, ed. G. C. Roberts (Champaign, II: Human Kinetics.

Smith, RE., Cumming, S. P., and Smoll, F. L. (2008). Development and validation et the motivational climate scale for youth sport. Applied Sport Psychology, 20, 116136, doi: 10.1080/10413200701790558.f

Tamminen, K. A., Poucher, Z. A., and Powialaitis, V. (2017). The car ride home an interpretive examination of parent-athlete sport conversation. Sport Exercise Performance Psychology, 6, 325-339.

Veskovic, A., Valdevit, Z., Dordevic-Nikie, M. (2013). Goal Orientation and Perception of Motivational Climate of different competition levels, Fasta Universitatis, Series: Physical Education and Sport, Vol. 11, 3, 337-345. White, S. A., Duda, J. L., Hart, S. (1992). An Exploratory Examination of the Parent-initiated Motivational Climate Questionnaire, Perceptual and Motor Skills, 75, 875-880

Wolfenden, L. E. \& Holt, N. L. (2005). Talent development in elite junior tennis: perceptions of players, parents, and coaches. Journal of Applied Sport Psychology, $17,108-126$.

Corresponding author: Prof. Tatiana Iancheva, DSc National Sports Academy "Vassil Levski" 21 Acad. Stefan Mladenov, str. Sofia, 1000, Bulgaria E-mail: iancheva.tatiana@gmail.com 